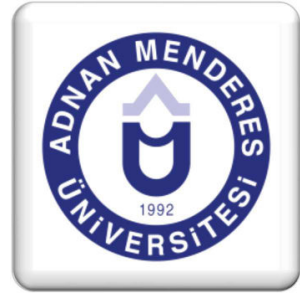

\section{Gecekonduyla Mücadeleden Kentsel Dönüşüme Türkiye'de Kentleşme Politikaları}

\section{From Battling against Squattering to Urban Renewal: Urban Policies in Turkey}

\section{Özet}

Gecekondulaşma, Türkiye'nin en önemli kentleşme sorunlarından biridir. Çok sayıda yasal düzenlemeye rağmen, gecekondu sorunu hala çözümlenememiştir. Yıllar içinde gecekondular ticari bir fonksiyon kazanmıştır.

Bu çalışmada öncelikle tarihsel perspektiften Türkiye'de uygulanan gecekondu yasaları, politikaları incelenmektedir. Ardından bir kentsel dönüşüm örneği olarak gecekondular üzerinde durulmaktadır. Son olarak 6306 sayılı Afet Riski Altındaki Alanların Dönüştürülmesi Hakkında Kanun ve uygulamaları değerlendirilmektedir.

Anahtar kelimeler: Gecekondulaşma, Kentsel Dönüşüm, 6306 s. Kanun

\section{Abstract}

The squattering is one of the most important urbanization problems in Turkey. Despite many legislative regulations, slum problem is still unresolved. Over the years, slums gained a commercial function.

Firstly, this study evaluates squattering laws and policies in Turkey from a historical perspective. Then, it examines slums as an example of urban renewal/transformation project. Finally, the study examines The Law for Transformation of Disaster Risk Areas (No. 6306) and its applications.

Key Words: Squattering, Urban Transformation, The Law No: 6306

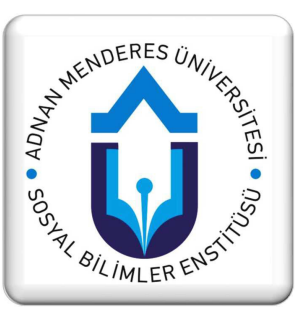

Fatma Neval

GENÇ*

*Doç. Dr.

Adnan Menderes

Üniversitesi

Nazilli İktisadi ve Ídari

Bilimler Fakültesi

Siyaset Bilimi ve Kamu

Yönetimi Bölümü 


\section{Giriş}

Türkiye'de 1950'lerde ülkenin sosyo-ekonomik yapısında yaşanmaya başlayan gelişmeler kentleşme hızının ve kentsel nüfusun artışına neden olurken, kentler bu yıllardan itibaren hiç görmedikleri ölçüde hızlı bir dönüşüm sürecine de girmişlerdir. Bu süreçte yeni merkezler ortaya çıkmış, merkezi iş alanları yıkılıp yapılarak yenilenmiş, kentlerin gelişme yönleri değişmiş, uydu kentlerle, eğitim kampüsleriyle kent çevresindeki yeşil alanlar ve tarım toprakları konut alanına dönüşmüştür (Tekeli, 1991: 41; Tekeli, 2001: 83; Kıray, 1982: 270). Bu dönüşüm sürecinde kentler plansız gelişmeleri yanında hem doğal, tarihi ve kültürel çevreyi hem de afet risklerini göz ardı ederek büyümüşlerdir.

Türkiye'de kentleşme ve planlama pratiğine kentsel dönüşüm kavramının girişi 1970'li yıllara, planlamada bir uygulama aracı olarak kullanılmaya başlanması ise 1980'lere denk düşmektedir (Sönmez, 2006: 121). 1980'lerde örnekler daha ziyade kent merkezindeki gecekondu alanlarının konut ihtiyacını giderme amacıyla yenilenmesi şeklinde olmuştur. 1996'da İstanbul'da düzenlenen HABİTAT II toplantısının ardından kentsel dönüşüm ulusal plan ve raporlarda, yeni bir yerel politika alanı olarak yerini almaya başlamıştır (Dursun ve Ekmekçi, 2010). Türkiye'de uygulana gelen kentsel dönüşüm projelerini türlerine göre şöyle sıralamak mümkündür (Genç, 2012: 149-152):

i) Merkezi iş alanlarının dönüşümü (Maslak-Büyükdere aksı, Şişli, Mecidiyeköy; Ankara'da Ulus ve çevresi); ii) Sit alanlarının korunması ve turizm amaçlı dönüşüm (Tarlabaşı, Sulukule, Dolapdere, Ankara'da Hacıbayram Camii ve Ulus merkezi iş alanı; İzmir'de Kemeraltı Çarşısı); iii) TOKİnin öncülügüünde başlatılan dönüşüm projeleri (İstanbul Park, Formula 1 Pisti, yat limanı, Sabiha Gökçen Havaalanı, Sabancı Üniversitesi; İzmir'de Konak, Uzundere Kentsel Yenileme Projeleri); iv) Büyük altyapı yatırımları, metro, ekspres yollar (1980 sonrasında Ankara'da Eskişehir Yolu üzerindeki yapılaşmalar; İstanbul Bilgi Üniversitesi kampusu); v) Doğal afetler nedeniyle kentsel dönüşüm (İstanbul'da Zeytinburnu, Bakırköy, Küçükçekmece; İzmir'de Ballıkuyu ve Vezirağa; 1999 depremlerinde hasar gören kentler); vi) Kentin boş ve uygun alanlarında yeni konut projeleri üretmek (Safir yaşam merkezi, Çekmeköy-Evidea Projesi); vii) Soylulaştırma (İstanbul'da kıyı kesimindeki tarihi yapılarda; 1970 ve 1980'lerde Kuzguncuk, Arnavutköy, Ortaköy, Cihangir, Beyoğlu, Galata, Balat ve Fener); viii) Çöküntü bölgelerinin/gecekondu alanlarının dönüşümü (Ankara'da Dikmen Vadisi ve Portakal Çiçeği Kentsel Dönüşüm Projeleri; Çankaya Belediyesi'nin GEÇAK, Koza Sokak ve Yıldızevler Özel Proje Alanı, Altındağ Aktaş-Atilla Dönüşüm Projesi, Mamak Belediyesi, Ege Mahallesi Kentsel Dönüşüm Projesi, Yenimahalle Belediyesi (Şirindere), Güneypark Konutları; İstanbul'da Tuzla, Beykoz, Sarıyer, Silivri'deki gecekondu bölgelerinin, eski sanayi alanlarının (Kağıthane Deresi ve çevresi, Pendik, Kartal sahili ve Maltepe'de eski mermer ocaklarının bulunduğu bölge; eski Beykoz Deri Kundura, Paşabahçe tesisleri), Sarı̈öl-Yenidoğan, Tozkoparan Mahallesi; Ayazma, Esenler, Başıüyük, İzmir'de İzmir-Narlıdere Kentsel Dönüşüm Projesi, Zafertepe Gecekondu Çevresi Geliştirme Projesi, Kadifekale, Karşıyaka-Şemikler, Ege Mahallesi, Konak Belediyesi Uzundere ve Ballıkuyu Mahalleleri; Bursa'da Doğanbey Kentsel Dönüşüm Projesi; Samsun'da Kıran ve Çay Mahalleleri).

Türkiye'de örnekleri görülen bu yenileme/dönüşüm türleri içinde, bu çalışmada daha ziyade gecekondu alanlarında yaşanan dönüşüm üzerinde yoğunlaşılacak ve tarihsel perspektiften Türkiye'de gecekondu politikaları genel olarak incelenerek 6306 sayılı Afet Riski Altındaki Alanlarının Dönüşümü Hakkında Yasa ve 5 Ekim 2012 günü Başbakan tarafından başlatılan kentsel dönüşüm hareketi çerçevesinde, Türkiye'de gecekondulaşma ve kentsel dönüşüm süreci değerlendirilecektir.

\section{Türkiye'de Gecekondulaşma Politikası}

Türkiye'de kentleşme sürecinin ve politikalarının önemli bir bölümünde gecekondulaşma olgusu ve bununla mücadele önemli bir yer tutmaktadır. Türkiye'de gecekondulaşma süreci, başlangıçta masum, barınma ihtiyacını karşılamaya dönük bir çaba olarak algılanırken, zaman içinde kısa vadeli siyasi kaygılarla, çoğu 'imar affi' olarak nitelenebilecek yasal düzenlemelerle arsa spekülasyonuna, rant maksimizasyonuna, 
"gecekondu ticaretine" dönüşmüştür. Kent toprağının artık daha az ve daha değerli hale gelmesi, kentlerin gelişmesi/genişlemesi ile eski gecekondu alanlarının kent merkezlerinde kalması, gecekondularla mücadeleyi yeni bir noktaya getirmiştir. Bu noktada artık çözümün adı "kentsel dönüşüm" dür (Mutlu, 2007: 39).

Son dönemde uygulanmaya başlanan kentsel dönüşüm politikalarına gelene kadar Türkiye'de gecekondu politikasının gelişimini; planlama öncesi dönem (1945-1960), planlama sonrası dönem (1960-1980); 1980 sonrası dönem (Geray, 1968: 21; Heper, 1979: 55); 2000 sonrası dönem ve nihayetinde 6306 sayılı Kanun çerçevesinde dönemlere ayırarak incelemek mümkündür.

\subsection{Planlama Öncesi Dönem (1945-1960)}

Türkiye'de ilk gecekondulaşma hareketleri 1930 'lu yıllarda Ankara- Altındağ'da başlamıştır. İkinci Dünya Savaşı sonrasında gecekondular kırdan kente göçenlerin tek barınma seçeneği olurken, bu dönemde "Konutu Olmayana Konut" politikası ile dar gelirlilerin vergi, kredi ve arsa tahsisi ile konut sahibi olması amaçlamıştır. 1960'lara kadar gecekondulaşmanın yıkımlarla önlenebileceği fikrine dayanan politikalar öndedir. Bu dönemdeki temel anlayış, kaçak yapıları mevzuata uydurmak ve düzeni korumaktır. Bunu, gecekondularda mahalleleşme dönemi takip etmiştir. Bu dönemde gecekondu politikalarında öne çıkan 3 nokta vardır; belediyelerin hazineden elde ettikleri arazileri vatandaşlara vererek gecekondulaşmayı önlemeye çalışmaları; gecekondu yapımının yasaklarla önlenebileceği düşüncesi ve son olarak da önceki dönemlerde yapılan gecekonduların yeni düzenlemelerle yasallaştırılması (Keleş, 2008: 596)

Bu dönemin gecekondulaşmaya ilişkin temel yasal düzenlemeleri şöyledir:

- (1948) 5218 s. Ankara'da Belediye ve Devlete ait Arsaların Mesken Yapacaklara Tahsisi Hakkında Yasa: Ankara Belediyesi sınırları içindeki gecekonduların durumunu iyileştirmeyi ve yeniden gecekondu yapacak olanlara on yıl geri ödemeli olarak arsa sağlayarak gecekonduculuğun önlenmesi amacıyla çıkarılan ilk yasadır. Arsa verilenlere en çok 2 yıl içinde yapı yapma zorunluluğu getirilmiştir. Ankara'da Yenimahalle bu dönemde kurulmuştur.

- (1948) 5228 s. Bina Yapımını Teşvik Yasası: Önceki yasayla arsa yardımı alanların konut kredisinden de yararlanmaları için çıkarılan bu yasayla ihtiyaç sahiplerine yapı parasının $\% 75^{\prime}$ ine kadar $\% 5$ faizli kredi alma hakkı tanınmıştır. Önceleri sadece Ankara'daki gecekonduları kapsamış, daha sonra kapsamı genişletilmiştir.

- (1949) 5431 s. Ruhsatsız Yapıların Yıktırılmasına Dair Yasa: Gecekondulaşmanın hızlanması ve mülkiyet haklarının zarar görmesi şikâyetleri ile gecekondulaşmanın önlenmesi ve yapılanların da yıkılmasını öngörmektedir.

- (1953) 6188 s. Bina Yapımını Teşvik ve İzinsiz Yapılar Hakkındaki Yasa: Belediyenin elindeki veya belediyeye türlü yollarla geçecek olan arsaların ihtiyaç sahiplerine temlik veya tahsis edilerek konut ihtiyacının giderilmeye çalışılmasını amaçlamıştır. Bu yasayla 1953 yılına kadar yapılmış olan gecekondular, yasallaştırılmış; bu tarihten sonra gecekondu yapımı ise yasaklanmıştır.

- (1959) 7367 s. Yasa: Hazine arazilerinden belediye sınırları içinde bulunanların gecekondu yapımını önlemek amacıyla imar planı olsun veya olmasın karşılıksız olarak belediyelere geçmesini öngörmüştür.

\subsection{Planlama Sonrası Dönem (1960-1980)}

Planlı dönemde, gecekondu sorununa Beş Yıllık Kalkınma Planları ile çözüm aranmaya başlanmıştır. Birinci planda (1963-1967) yıkım yerine öncelikle 1slah/iyileştirme stratejisi, ikinci yol olarak tasfiye/ortadan kaldırma ve son yöntem olarak da önleme, bu dönem politikalarda hâkimdir. İkinci planda (1967-1972) önlemeye öncelik verilmiştir. Konut yapımında gecekondu sahibinin emeğinden de faydalanılması amaçlanmış ancak imece yönteminden beklenen başarı elde edilememiştir. Üçüncü planda (1973-1977) 
gecekondulaşmanın ekonomik büyüme ile çözümlenebileceği fikri hâkimdir. Dördüncü planda (1978-1983) gecekondulara altyapı hizmetlerinin götürülmesinden söz edilse de bu gerçekleşmemiştir.

Gecekondu önleme bölgeleri, toplu konut uygulamaları bu dönemde hız kazanmıştır. Batıkent, Ak-kondu gibi projelere bu yıllarda girişilmiştir. Ancak yeterli konut ve ucuz arsa üretilememesi nedeniyle bu projeler başarısız olurken taleple beraber gecekondu mahallelerinin sayıları artmış, gecekonducular birer baskı grubuna dönüşmüştür. 1970'lerde gecekondular, kendi sektörünü, patronunu, mafyasını yaratmaya başlamıştır. 1960'ların başlarında Türkiye'de 240.000 civarında gecekondu varken, İstanbul'da nüfusun $\% 21$ 'i, Ankara'da \%45'i gecekondularda yaşamaktadır. 1965 'lerde gecekondu sayısı 430.000 'e yaklaşmış ve 1970 'lerde bunu aşmıştır.

Bu dönemde çıkarılan başlıca yasalar şunlardır:

- (1963) 327 s. Yasa: Kaçak yapılara da kent hizmetlerinin götürülmesini öngörmüştür.

- (1966) 775 s. Gecekondu Yasası: Bugün uygulanmakta olan politikanın temel adımlarını içeren yasadır. Daha önceki yasalarda olduğu gibi iyileştirme, ortadan kaldırma ve önleme amaçlarını taşır. Yasa ile iyileştirme ve ortadan kaldırma bölgelerinin belediyeler tarafından altı ay içinde belirlenmesi, krokilerinin çizilmesi; belediyelerin gecekonduları önleme amacıyla arsa edinmesi, bu arsaları nihayetinde tamamen vatandaşın olacak şekilde terk etmek üzere kullanması hükme bağlanmıştır. Gecekondu yasası, arsa yardımı alanların konut ihtiyacını karşılamak için çeşitli yardımlar öngörmüştür. Bunlardan biri, gecekondu fonlarından mali yardım yapmaktır. Bu fonlardan biri belediyelerin diğeri de Bayındırlık ve İskân Bakanlığı'nın denetiminde olmak üzere oluşturulmuştur (Keleş, 2008: 605).

- (1976) 1990 s. Gecekondu Yasasında Bazı Değişiklikler Yapılması Hakkında Yasa: 1973 sonuna kadar yapılan gecekonduların bağışlanacağını ifade etmektedir.

\subsubsection{0 sonrası dönem (1980-2000)}

$\mathrm{Bu}$ dönemde gecekondular ticarileşmiş; piyasa mekanizmasının bir ürünü haline gelmiş; barınma ihtiyacını gidermekten ziyade rant elde etme aracı olmuşlardır. Gecekondu alanlarının dönüştürülmesinde ıslah imar planları ile bu alanların yenilenerek kentsel arsa pazarına tekrar sunulması esas araç olmuştur. Bu dönemde de, gecekonduların affına yönelik bir dizi yasa çıkarılmış ve bu dönemde gecekondu alanlarının yasallaştırılması ve dönüşümü, gecekondu sahipleri ve hükümetler arasında sürekli bir pazarlık konusu olmuştur. 1980'lerin sonuna gelindiğinde, başta yerel yönetimler olmak üzere, kamu-özel sektör işbirliği ile geliştirilen, yüksek rantlı alanlarda uygulamaya konan ve ıslah-imar planlarına tek alternatif olarak görülen özel kentsel dönüşüm projeleri uygulamaları başlamıştır.

Bu dönemde gecekondu politikalarına altlık oluşturan başlıca yasal düzenlemeler ise şunlardır:

- (1983) 2805 s. İmar ve Gecekondu Mevzuatına Aykırı Olarak Yapılan Yapılara Uygulanacak İşlemler ve 6785 Sayılı İmar Yasası'nın Bir Maddesinin Değiştirilmesi Hakkında Yasa: Gecekondu affının açıkça gündeme geldiği bu düzenlemede imara aykırı yapı ve gecekondular affedilerek, sağlıklaştırılarak yasal hale getirilmeleri amaçlanmıştır.

- (1983) 2960 Sayılı Boğaziçi Yasası: 2805 sayılı yasanın Boğaziçi Alanını kapsamaması nedeniyle bu yasa ile Boğaziçi ve çevresinin kentsel değişime paralel olarak değerinin azalmasına engel olmak için bu bölgenin korunarak imar mevzuatının düzenlenmesi amaçlanmıştır. Bu yasa ile ıslah planları ile imar mevzuatına aykırı yapılmış yapıların bağışlanması amaçlanmıştır.

- (1984) 2981 s. İmar ve Gecekondu Mevzuatına Aykırı Olarak Yapılan Yapılara Uygulanacak Bazı İşlemler ve İmar Yasasının Bir Maddesinin Değiştirilmesi Hakkında Yasa: 2805 ve ardından 2981 sayılı yasalar, Eylül 1980'de gecekondu yapımının bir bildiriyle yasaklandığı tarihten Haziran 1981'e kadar yapılan gecekonduları bağışlamıştır. Gecekonduyla ilgili yasal düzenlemelerin en kapsamlısı olarak değerlendirilen 
yasa çok küçük bölgeler dışında hem gecekonduları hem imarlı alanlardaki yapıları af kapsamına alarak çok geniş bir alana yayılmıştır. Yasayla bağışlanacak gecekondular için işlemlerin kolaylaştırılması, cezaların azaltılması ya da kaldırılması, af kapsamının zaman ve kapsam yönünden genişletilmesi öngörülmüştür. Yasa ile gecekondularda kat sayısının artması, gecekonduların alınıp satılması ve müteahhitlere verilmesi mümkün hale gelmiştir. Arazinin temizlenerek altyapısının getirilmesi ve parselasyon yapımından ilgili belediye sorumlu tutulmuştur.

- 247 ve 250 Sayılı Kanun Hükmünde Kararnameler: Belediyelerce yapılan veya yaptırılan gecekondu tasfiye, islah ve önleme bölgelerine ait projelere dayanılarak, TOKİ tarafından kamulaştırma, arazi ıslah ve düzenlemesi, altyapı işlemleri ve bina yapımı için karşılıklı veya karşılıksız yardım yapılabileceği hükme bağlanmıştır.

- (1986) 3414 Sayılı Yasa: Bu yasa ile 247 ve 250 sayılı Kanun Hükmünde Kararnameler yasalaşmış, Bayındırlık ve İskân Bakanlığı'nın gecekondularla ilgili yetkileri imar yasasının bu bölgelerin imar planlarının yapılmasına ilişkin olarak, imar yasasının bakanlığa verdiği özel yetkiyle sınırlandırılmıştır. 775 sayılı yasa ile belediye ve mücavir alan sınırları içinde kalan gecekondularla ilgili yetkileri büyükşehir belediyesi ve valiliklere vermişken bu yasa, söz konusu yetkileri ilçe belediyelerine devretmiştir. 3414 yasanın bazı hükümleri, gecekondu sahiplerinin arsasını veya konutunu müteahhide vermesi veya satarak başka yerde yeni bir gecekondu yapmasına neden olmuştur. 3414 sayılı yasa, getirdiği haklarla gecekondu ve kaçak yapılara yasal nitelik kazandırarak arsa pazarına katılmasına katkıda bulunmuştur.

- (1986) 3290 Sayılı Yasa: Bu kanunla 2981'in süre ve kapsamı genişletilerek daha önce konut olarak kullanılıp sonradan işyerine çevrilen gecekondular da yasaya dâhil edilerek gecekondulaşma adeta teşvik edilmiştir. 2981 sayılı yasa ile kamu arazileri gecekondu sahiplerine rayiç bedel üzerinden verilirken bu yasa ile beyan esasına dönüşmüş ve böylece kamu mülkiyetindeki arsa ve araziler çok düşük miktarlar karş1lığı verilmiştir. Islah imar planlarının onayı Bayındırlık ve İskân Bakanlığı'ndan alınarak bu yasa ile yerel yönetimlere devredilmiştir. Bu yasa ile gecekondu sahiplerine tapu verme işlemlerinin kolaylaştırılmasına çalışılmış, af kapsamı genişletilerek gecekondu alanları potansiyel kentsel arsa stoğu olarak benimsenmiş ve bu yaklaşım kamu arsa ve arazilerini spekülatörlere açık hale getirmiştir.

- (1987) 3366 Sayılı Yasa: Gecekondulardan ek harç alınması koşuluyla başvuru süreleri uzatılmış, kamu sahipliğindeki arazilere kişi sahipliğindeki arsalar da katılmış, yapı ruhsatı ve tapu verme işlemleri kolaylaştırılmıştır. Yasa ile gecekondu tanımına çeşitlilik getirilerek kaçak yapılmış her tür yapı gecekondu gibi yorumlanarak bu yapı sahiplerine de sslah bölgesi veya yakın çevresinden bağımsız, hisseli veya kat mülkiyeti esasına göre imar parseli verilebileceği hükme bağlanmıştır.

\subsection{Sonrası Dönem: Gecekonduyla Mücadele Kentsel Dönüşüm Yaklaşımı}

2000'li yıllara gelindiğinde ise gecekondu sorununa kentsel dönüşüm yaklaşımı ile çözüm aranmaya başlanmıştır. Özellikle Marmara ve Düzce Depremlerinin ardından oluşan duyarlılıkla afetler karşısında risk azaltımı araçlarından biri olarak kentsel dönüşüm gündeme gelmiştir. Bayındırlık ve İskân Bakanlığı'nın 2004 yılında düzenlediği Deprem Şurası'nın Mevzuat Komisyonu Raporunda (BİB, 2004: 7) "kentsel dönüşüm eylem planları" tanımlanırken; 2004-Türkiye İktisat Kongresi Afet Komisyonu Raporunda da sakınım planları kapsamında yerel yönetimlerin kentsel dönüşüm alanlarında boşaltma, yenileme, güçlendirme araçlarının geliştirilmesi önerilmektedir (DPT, 2004: 15).

Türkiye'de gecekonduların kentsel dönüşümün uygulama alanlarından bir olmasında gerek ulusal ölçekte kalkınma planları ve hükümet programları, gerekse yerel ölçekte imar planları ve 2004 yılında "Kentsel Dönüşüm Kanun Taslağı”nın etkisi vardır. Taslakta, mevzuata aykırı yapılar, gecekondu bölgeleri ve afet riski taşıyan bölgelere ilişkin düzenlemeler getirileceği belirtilmektedir. 2004 yılı ve sonrasında $\mathrm{AB}$ ile uyum yasalarında kentsel dönüşüm konusu yoğun biçimde yer almaya başlamıştır. Bunlar yanında 2000'li yıllarda yenilenen yerel yönetim yasalarında kentsel dönüşüm konusunu içeren düzenlemeler yapılmıştır. 
5216 sayılı Büyükşehir Belediyeleri Kanununda (2004) Büyükşehir belediyeleri kentsel dönüşüm konusunda yetkilendirilirken, 5393 Sayılı Belediye Kanunu (2005) ile ilk kez belediyelere kentsel dönüşüm konusunda görevler verilmiştir. Kanunun arsa ve konut üretimi başlıklı 69. maddesinde, belediyelerin düzenli kentleşmeyi sağlamak, konut ihtiyacını gidermek amacıyla arazi sağlama, konut ve yapma/yaptırma, yetkisi belirtilmekte ve nihayetinde 73. Maddesinde, "Belediye, kentin gelişimine uygun olarak eskiyen kent kısımlarını yeniden inşa ve restore etmek; konut alanları, sanayi ve ticaret alanları, teknoloji parkları ve sosyal donatılar oluşturmak, deprem riskine karşı tedbirler almak veya kentin tarihî ve kültürel dokusunu korumak amaciyla kentsel dönüşüm ve gelişim projeleri uygulayabilir...Bir yerin kentsel dönüşüm ve gelişim proje alanı olarak ilân edilebilmesi için; o yerin belediye veya mücavir alan sınırları içerisinde bulunması ve en az elli bin metrekare olması şarttır...."denilerek belediyelerin kentsel dönüşüme ilişkin görevleri tanımlanmıştır. Bu yasa ile imar planlarının yapılması, onaylanması, kentsel dönüşüm ve gelişim projelerini uygulama yetkisi Büyükşehir Belediyelerine verilmiştir.

5104 sayılı Kuzey Ankara Girişi Kentsel Dönüşüm Projesi Kanunu (2004) doğrudan kentsel dönüşümle ilgili olarak çıkarılan ilk kanundur. Ankara'da "Protokol Yolu" olarak ifade edilen Esenboğa'da, farklı belediyelerin yetki alanı içindeki gecekondular, zaman içinde ıslah imar planları ile dönüştürülüp kente kazandırılamamıştır. Yasa gecekonduların dönüştürülmesi işini Ankara Büyükşehir Belediyesine vererek bu soruna çözüm getirmek amacıyla hazırlanmıştır.

5366 sayılı Yıpranan ve Tarihi ve Kültürel Taşınmaz Varlıkların Yenilenerek Korunması ve Yaşatılarak Kullanılması Hakkında Kanunun (2005) ${ }^{1}$ amacı (m.1), "Büyükşehir belediyeleri ve Büyükşsehir belediye sınırları içindeki ilçe ve ilk kademe belediyeleri, il, ilçe belediyeleri, nüfusu 50 bini geçen belediyelerce ve bu belediyelerin yetki alanı dışında il özel idarelerince yıpranan ve özelliğini kaybetmeye yüz tutmuş kültür ve tabiat varlıklarını koruma kurullarınca sit alanı olarak tescil ve ilan edilen bölgeler ile bu bölgelere ait koruma alanlarının bölgenin gelişimine uygun olarak yeniden inşa ve restore edilerek bu bölgelerde konut, ticaret, kültür, turizm ve sosyal donatı alanları oluşturulması, doğal afet risklerine karşı önlem alınması, tarihi ve kültürel taşınmaz varlıkların yenilenerek korunması ve yaşatılarak kullanılması" olarak belirtilmekte; ikinci maddesinde, "Yenileme alanları, il özel idarelerinde il genel meclisi, belediyelerde belediye meclisi üye tam sayısının salt çoğunluğunun kararı ile belirlenir. İl özel idaresinde il genel meclisince, büyükşehirler dışındaki belediyelerde belediye meclisince alınan kararlar Bakanlar Kuruluna sunulur. Büyükşehirlerde ise ilçe ve ilk kademe belediye meclislerince alınan bu kararlar, büyükşehir belediye meclisince onaylanması halinde Bakanlar Kuruluna sunulur. Bakanlar Kurulu projenin uygulanıp uygulanmamasına üç ay içinde karar verir..." denilerek bu konudaki karar verme yetkisi belirtilmektedir.

\section{6306-Afet Riski Altındaki Alanların Dönüştürülmesi Hakkında Kanun ve Uygulamaya Yansımaları}

Kentsel dönüşüm konusunda atılan en önemli adımlardan biri, Dönüşüm Alanları Hakkında Kanun Tasarısı'dır ${ }^{2}$. Tasarının genel gerekçesinde 1950 'lerden bu yana süregelen hızlı ve sağlıksız kentleşme eğilimi, bölgeler arası gelişme farkları, orman, kıyı ve tarım alanları, su havzalarının yerleşime açılması gibi kentleşme özelliklerinden, bu sorunlara çözüm olarak geçmişte geliştirilmiş olan öneriler ve bunların yetersizliklerinden söz edilerek genel gerekçede "fiziki mekanın güvenli, nitelikli, yaşanabilir kılınması için afet riski taşıyan alanların, fiziki, sosyal ve ekonomik köhneleme alanlarının, korunması gerekli doğal, tarihi ve kültürel çevre alanlarının toplum yararı esas alınarak dönüşüm plan ve projeleri kapsamında tasfiye, yenileme, iyileştirmeye tabi tutulması gerektiği" belirtilmektedir. Genel gerekçede ayrıca, 5366 sayılı kanunun sadece "sit alanı olarak tescil ve ilan edilmiş olan alanlarda kalan yıpranan tarihi ve kültürel taşınmaz varlıkların yenilenerek korunmasını esas alması" ve 5393 sayılı Belediye Kanununun 73. maddesi

\footnotetext{
${ }^{1} 1$ Mart 2005'te “ Kentsel Dönüşüm ve Gelişim Kanunu” adı altında TBMM'ye sunulan taslak, 16 Haziran 2005'te "5366 Sayılı Yıpranan ve Tarihi ve Kültürel Taşınmaz Varlıkların Yenilenerek Korunması ve Yaşatılarak Kullanılması Hakkında Kanun" adıyla yürürlüğe girmiştir.

${ }^{2} 22$ Haziran 2006 tarihinde Meclise sunulmuştur.
} 
ile belediyelere kentsel dönüşüme ilişkin görevler verilmesinin doğurduğu yeni yasal düzenleme gerekliliği belirtilmektedir.

Söz konusu tasarı, 16.5.2012 tarihinde yasalaşmıştır. Kentsel dönüşüm çerçevesinde gecekondulaşma ve diğer kentsel sorunlarla mücadele yönünde çıkarılan en önemli yasal düzenlemelerden biri $6306 \mathrm{~s}$. Afet Riski Altındaki Alanların Dönüştürülmesi Hakkında Kanun'dur. Kanunun ardından 4.8.2012 ${ }^{3}$ tarihli Resmi Gazetede Kanunun Uygulama Yönetmeliği çıkarılmıştır.

Kanunun öncelikli hedefi afet riski altındaki alanları dönüştürmektir: (m.1); "Bu Kanunun amacı; afet riski altındaki alanlar ile bu alanlar dişındaki riskli yapıların bulunduğu arsa ve arazilerde, fen ve sanat norm ve standartlarına uygun, sağlıklı ve güvenli yaşama çevrelerini teşkil etmek üzere iyileştirme, tasfiye ve yenilemelere dair usul ve esasları belirlemektir."

Kanunun uygulanmasında sorumlu bakanlık olarak Çevre ve Şehircilik Bakanlığı ile TOKİ belirtilmekte ve bunun yanında kanunun esasını oluşturan rezerv yapı alanı, riskli alan ve riskli yapı kavramları tanımlanmaktadır (m.2). Buna göre, "İdare: Belediye ve mücavir alan sinırları içinde belediyeleri, bu sinırlar dışında il özel idarelerini, büyükşehirlerde büyükşehir belediyelerini ve Bakanlık tarafindan yetkilendirilmesi hâlinde büyükşehir belediyesi sınırları içindeki ilçe belediyelerini, Rezerv yapı alanı: Bu Kanun uyarınca gerçekleştirilecek uygulamalarda yeni yerleşim alanı olarak kullanılmak üzere, TOKI'nin veya İdarenin talebine bağlı olarak veya resen, Maliye Bakanlığının uygun görüşü alınarak Bakanlıkça belirlenen alanları; Riskli alan: Zemin yapısı veya üzerindeki yapılaşma sebebiyle can ve mal kaybina yol açma riski taşıyan, Bakanlık veya İdare tarafindan Afet ve Acil Durum Yönetimi Başkanlığının görüşü de alınarak belirlenen ve Bakanlığın teklifi üzerine Bakanlar Kurulunca kararlaştırılan alanı; Riskli yapı: Riskli alan içinde veya dışında olup ekonomik ömrünü tamamlamış olan ya da yıkılma veya ağır hasar görme riski taşıdığı ilmî ve teknik verilere dayanılarak tespit edilen yapıyı" ifade etmektedir.

Kanun, riskli yapıların tespitinin nasıl, kimler tarafından yapılacağını, devir ve tescil işlemleri ile bunlara ilişkin süreleri de belirlemiştir (m.3):

(1) Riskli yapıların tespiti, Bakanlıkça hazırlanacak yönetmelikte belirlenen usul ve esaslar çerçevesinde masrafları kendilerine ait olmak üzere, öncelikle yapı malikleri veya kanuni temsilcileri tarafindan, Bakanlıkça lisanslandırılan kurum ve kuruluşlara yaptırılır ve sonuç Bakanlığa veya İdareye bildirilir. Bakanlık, riskli yapıların tespitini süre vererek maliklerden veya kanuni temsilcilerinden isteyebilir. Verilen süre içinde yaptırılmadı̆̆ takdirde, tespitler Bakanlıkça veya İdarece yapılır veya yaptırılır. Bakanlık, belirlediği alanlardaki riskli yapıların tespitini süre vererek İdareden de isteyebilir. Bakanlıkça veya İdarece yaptırılan riskli yapı tespitlerine karşı maliklerce veya kanuni temsilcilerince onbeş gün içinde itiraz edilebilir. Bu itirazlar, Bakanlı̆̆ın talebi üzerine üniversitelerce, ilgili meslek disiplini öğretim üyeleri arasından görevlendirilecek dört ve Bakanlıkça, Bakanlıkta görevli üç kişinin iştiraki ile teşkil edilen teknik heyetler tarafindan incelenip karara bağlanır. Bakanlı veya İdare tarafindan yapılan tespit işleminin masrafi ilgili tapu müdürlüğ̈̈ne bildirilir. Tapu müdürlüğ̈̈, binanın paydaşlarının müteselsil sorumlu olmalarını sağlamak üzere tapu kaydındaki arsa payları üzerine, masraf tutarında müşterek ipotek belirtmesinde bulunarak Bakanllğa veya İdareye ve binanın ayni ve şahsi hak sahiplerine bilgi verir.

\footnotetext{
${ }^{3}$ Buna İlaveten 13/9/2012 tarihli ve 28410 sayılı Resmî Gazete'de yayımlanan Dönüşüm Projeleri Özel Hesabı Gelir, Harcama, Kredi ve Kaynak Aktarımı Yönetmeliğinin ile 14.8.2013 tarihli Dönüşüm Projeleri Özel Hesabı Gelir, Harcama, Kredi ve Kaynak Aktarımı Yönetmeliğinde Değiş̧iklik Yapılmasına Dair Yönetmelik; Kamunun Mülkiyetinde veya Kullanımında Olan Yerlerde Kentsel Dönüşüm ve Gelişim Alanı İlan Edilmesinin Usul ve Esaslarına İlişkin Tebliğ (14.7.2012); 6306 sayılı Kanun Kapsamında Hak Sahiplerine Yapılacak Kira Yardımlarına İlişkin Genelge (27.3.2013); Riskli Yapı Tespiti Çalışmalarına İlişkin Genelge; Riskli Yapıların Yıktırılması Süreci ve Takibine İlişkin Genelge (27.3.2013) de yayımlanmıştır.
} 
(2) Riskli yapılar, tapu kütüğ̈̈nün beyanlar hanesinde belirtilmek üzere, tespit tarihinden itibaren en geç on iş günü içinde Bakanlık veya İdare tarafından ilgili tapu müdürlüğüne bildirilir. Tapu kütüğ̈̈ne işlenen belirtmeler hakkında, ilgili tapu müdürlüğünce ayni ve şahsi hak sahiplerine bilgi verilir.

Kanuna göre (m.4) riskli binalarda tespitin ardından yıkılmaya kadar olan dönemde birtakım tasarrufların kısıtlanması yoluna gidilebilir:

1) Bakanlık veya uygulamayı yürütmesi hâlinde TOKİ veya İdare, riskli alanlarda, riskli yapıların bulunduğu taşınmazlarda ve rezerv yapı alanlarında bu Kanun kapsamindaki proje ve uygulamalar süresince her türlü imar ve yapılaşma işlemlerini geçici olarak durdurabilir.

(2) 3 üncü maddenin üçüncü fikrasında belirtilen taşınmazlar, tahsis ve devir işlemleri sonuçlandırılıncaya kadar Maliye Bakanlığınca satılamaz, kiraya verilemez, tahsis edilemez, ön izne veya irtifak hakkına konu edilemez.

(3) Uygulama sırasında Bakanlık, TOKİ veya İdare tarafindan talep edilmesi hâlinde, hak sahiplerinin de görüşü alınarak, riskli alanlardaki yapılar ile riskli yapılara elektrik, su ve doğal gaz verilmez ve verilen hizmetler kurum ve kuruluşlar tarafindan durdurulur.

Kanunda (m.5) tahliye ve yıkılma işlemlerinde geçerli olacak hükümler de belirlenmiştir. Buna göre;

(1) Riskli yapıların yıktırılmasında ve bunların bulunduğu alanlar ile riskli alanlar ve rezerv yapı alanlarındaki uygulamalarda, öncelikli olarak malikler ile anlaşma yoluna gidilmesi esastır. Anlaşma ile tahliye edilen yapıların maliklerine veya malik olmasalar bile kiracı veya sinırl ayni hak sahibi olarak bu yapılarda ikamet edenlere veya bu yapılarda işyeri bulunanlara geçici konut veya işyeri tahsisi ya da kira yardımı yapılabilir.

(2) Uygulamanın gerektirmesi hâlinde, birinci fikrada belirtilenler dışında olup riskli yapıyı kullanmakta olan kişilere de birinci fikra hükümleri uygulanabilir. Bu kişiler ile yapılacak olan anlaşmanın, bunlara yardım yapılmasının ve enkaz bedeli ödenmesinin usul ve esaslarl Bakanlı̆̆ın teklifi üzerine Bakanlar Kurulunca belirlenir.

(3) Uygulamaya başlanmadan önce, riskli yapıların yıktırılması için, bu yapıların maliklerine altmış günden az olmamak üzere süre verilir. Bu süre içinde yapı, malik tarafindan yıktırılmadığı takdirde, yapının idari makamlarca yıktırılacăğ belirtilerek ve tekrar süre verilerek tebligatta bulunulur. Verilen bu süre içinde de maliklerince ylktırma yoluna gidilmediği takdirde, bu yaplların insandan ve eşyadan tahliyesi ve ylktırma işlemleri, yıktırma masrafı ile gereken diğer yardım ve krediler öncelikle dönüşüm projeleri özel hesabından karşılanmak üzere, mahallî idarelerin de iştiraki ile mülki amirler tarafindan yapılır veya yaptırılır.

(4) Birinci, ikinci ve üçüncü fikralarda belirtilen usullere göre süresinde yıktırllmadı̆̆ tespit edilen riskli yapıların yıktırılması, Bakanlıkça yazılı olarak İdareye bildirilir. Buna rağmen yıktırılmadı̆̆ tespit edilen yapılar, Bakanlıkça yıkılır veya yıktırılır. Uygulamanın gerektirmesi hâlinde Bakanlık, yukarıdaki fikralarda belirtilen tespit, tahliye ve yıktırma iş ve işlemlerini bizzat da yapabilir.

(5) Bakanlık veya İdare tarafindan yapılan ylktırmanın masraflarl, ilgili tapu müdürlüğüne bildirilir. Tapu müdürlüğü, yıkllan binanın paydaşlarının müteselsil sorumlu olmalarını sağlamak üzere tapu kaydındaki arsa paylarl üzerine masraf tutarında müsțterek ipotek belirtmesinde bulunarak Bakanliğa veya İdareye ve binanin ayni ve şahsi hak sahiplerine bilgi verir.

Kanun (m. 6) uygulamanın nasıl yapılacağını da ayrıntılı olarak aktarmaktadır:

(1) Üzerindeki bina yıkılarak arsa hâline gelen taşınmazlarda daha önce kurulmuş olan kat irtifakı veya kat mülkiyeti, ilgililerin muvafakatleri aranmaksızın Bakanlı̆̆ın talebi üzerine ilgili tapu müdürlüğ̈̈nce resen terkin edilerek, önceki vasfı ile değerlemede bulunularak veya malik ile yapılan anlaşmanın şartları tapu kütü̈̆̈̈̈nde belirtilerek malikleri adına payları oranında tescil edilir. Bu taşınmazların sicilinde bulunan taşınmazın niteliği, ayni ve şahsi haklar ile temlik hakkını kısıtlayan veya yasaklayan her türlü şerh, hisseler üzerinde devam eder. Bu şekilde belirlenen uygulama alanında cins değişikliği, tevhit ve ifraz işlemleri 
Bakanlık, TOKİ veya İdare tarafindan resen yapılır veya yaptırllır. Bu parsellerin malikleri tarafindan değerlendirilmesi esastır. Bu çerçevede, parsellerin tevhit edilmesine, münferit veya birleştirilerek veya imar adası bazında uygulama yapılmasına, yeniden bina yaptırılmasına, payların satışına, kat karşıllğı veya hasılat paylaşımı ve diğer usuller ile yeniden değerlendirilmesine sahip oldukları hisseleri oranında paydaşların en az üçte iki çoğunluğu ile karar verilir. Bu karara katılmayanların bağımsız bölümlerine iliş̧kin arsa payları, Bakanlıkça rayiç değeri tespit ettirilerek bu değerden az olmamak üzere anlaşma sağlayan diğer paydaşlara açık artırma usulü ile satılır. Bu suretle paydaşlara satı̧s gerçekleştirilemediği takdirde, bu paylar, Bakanlığın talebi üzerine, tespit edilen rayiç bedeli de Bakanlıkça ödenmek kaydı ile tapuda Hazine adına resen tescil edilir ve yapılan anlaşma çerçevesinde değerlendirilmek üzere Bakanlığa tahsis edilmiş sayllır veya Bakanlıkça uygun görülenler TOKI'ye veya İdareye devredilir. Bu durumda, paydaşların kararı ile yapılan anlaşmaya uyularak işlem yapılır.

(2) Üzerindeki bina yıkılmış olan arsanın maliklerine yapılan tebligatı takip eden otuz gün içinde en az üçte iki çoğunluk ile anlaşma sağlanamaması hâlinde, gerçek kişilerin veya özel hukuk tüzel kişilerinin mülkiyetindeki taşınmazlar için Bakanlık, TOKİ veya İdare tarafindan acele kamulaştırma yoluna da gidilebilir. Bu Kanun uyarınca yapılacak olan kamulaştırmalar, 4/11/1983 tarihli ve 2942 sayll Kamulaştırma Kanununun 3 üncü maddesinin ikinci fikrasındaki iskân projelerinin gerçekleştirilmesi amaçlı kamulaştırma sayılır ve ilk taksit ödemesi, mezkûr fikraya göre belirlenen tutarların beşte biri oranında yapılır. Tapuda mülkiyet hanesi açık olan taşınmazlar ile mirasçısı belirli olmayan, kayyım tayin edilmiş, ihtilaflı veya üzerinde sınırlı ayni hak tesis edilmiş olan taşınmazların kamulaştırma işlemleri aynı madde hükümlerine tabidir. Bakanlık, TOKI veya İdare; kamulaştırma işlemlerinin yürütülmesi için mirasçılık belgesi çıkartmaya, kayyım tayin ettirmeye veya tapuda kayıtlı son malike göre işlem yapmaya yetkilidir.

Tapuda kayıtlı malikin ölmüş olması hâlinde Bakanlık, TOKİ veya İdare, kamulaştırma işlemi için mirasçıllk belgesi çıkartabileceği gibi, gerekiyorsa tapu sicilinde idari müracaat veya dava yolu ile kayıt düzeltme de isteyebilir. Kamulaştırma için anlaşma sağlanması hâlinde, Bakanlık, TOKİ veya İdare ile ilgililer arasında taşınmazın tescil veya terkinine ilişsin feră̆ ve muvafakati de ihtiva eden sözleşme ve uzlaşma tutanağl tanzim edilir ve ilgili tapu müdürlüğüne gönderilerek kamulaştırmanın resen tapu siciline işlenmesi să̆lanır.

(3) Anlaşma ile tahliye edilen, yıktırılan veya kamulaştırılan yapıların maliklerine ve malik olmasalar bile bu yapılarda kiracı veya sinırl ayni hak sahibi olarak en az bir yıldır ikamet ettiği veya bunlarda isyeri bulunduğu tespit edilenlere konut, işyeri, arsa veya dönüşüm projeleri özel hesabından kredi veya mülkiyet ya da sınırlı ayni hak sağlayan ve usul ve esasları Bakanlıkça belirlenen konut sertifikası verilebilir. Bunlardan konutunu ve işyerini kendi imkânlart ile yapmak veya edinmek isteyenlere de kredi verilebilir. 20/7/1966 tarihli ve 775 sayll Gecekondu Kanununa göre yoksul veya dar gelirli olarak kabul edilenlere verilecek olan konut veya işyerleri; Bakanlık, TOKI veya İdare tarafindan, 15/5/1959 tarihli ve 7269 sayll Umumi Hayata Müessir Afetler Dolaylsıyla Alınacak Tedbirlerle Yapllacak Yardımlara Dair Kanunda belirtilen usul ve esaslar uyarınca borçlandırma suretiyle de verilebilir.

(4) Riskli alanlarda, rezerv yapı alanlarında ve riskli yapıların bulunduğu taşınmazlar üzerinde yapımı gerçekleştirilen konutların bedelleri, gerekli görüldüğünde, proje uygulamalarının yapıldı̆̆ı illerdeki mevcut ekonomik durum, tabii afetin ortaya çıkardı̆̆ı durumlar, konut rayiç ve enkaz bedelleri ile uygulama alanındaki kişilerin mal varllğ̆l ve geliri göz önünde bulundurularak Bakanlar Kurulu kararı ile yapım maliyetlerinin altında tespit edilebilir ve sosyal donatı ve altyapı harcamaları uygulama maliyetine dâhil edilmeyebilir.

\section{(5) Bakanllk;}

a) Riskli yapılara, rezerv yapı alanlarına ve riskli yapıların bulunduğu taşınmazlara ilişskin her tür harita, plan, proje, arazi ve arsa düzenleme işlemleri ile toplulaştırma yapmaya, 
b) Bu alanlarda bulunan taşınmazları satın almaya, ön alım hakkını kullanmaya, bağımsız bölümler de dâhil olmak üzere taşınmazları trampaya, taşınmaz mülkiyetini veya imar haklarını başka bir alana aktarmaya,

c) Aynı alanlara ilişkin taşınmaz mülkiyetini anlaşma sağlanmak kaydı ile menkul değere dönüştürmeye,

ç) Kamu ve özel sektör işbirliğine dayanan usuller uygulamaya, kat veya hasılat karşıllı̆̆ usulleri de dâhil olmak üzere inşaat yapmaya veya yaptırmaya, arsa paylarını belirlemeye,

d) 23/6/1965 tarihli ve 634 sayll Kat Mülkiyeti Kanunundaki esaslara göre paylaştırmaya, payları ayırmaya veya birleștirmeye, 22/11/2001 tarihli ve 4721 sayılı Türk Medenî Kanunu uyarınca sınırlı ayni hak tesis etmeye, yetkilidir. (ç) bendinde belirtilen uygulamalar, 4/1/2002 tarihli ve 4734 sayll Kamu İhale Kanununa tabi idareler ile iş birliği içinde veya gerçek ve özel hukuk tüzel kişileri ile özel hukuka tabi anlaşmalar çerçevesinde de yapılabilir.

(6) Bakanlık, riskli alanlardaki ve rezerv yapı alanlarındaki uygulamalarda faydalanılmak üzere; özel kanunlar ile öngörülen alanlara ilişkin olanlar da dâhil, her tür ve ölçekteki planlama işlemlerine esas teşkil edecek standartları belirlemeye ve gerek görülmesi hâlinde bu standartları plan kararları ile tayin etmeye veya özel standartlar ihtiva eden planlar yapmaya, onaylamaya ve kent tasarımlarl hazırlamaya yetkilidir.

(7) Bu Kanun çerçevesinde dönüştürmeye tabi tutulan taşınmazların, üzerindeki köhnemiş yapılar da dâhil olmak üzere, muhdesatı ile birlikte değer tespiti işlemleri ve dönüşüm ile oluşacak taşınmazların değerlemeleri Bakanlık, TOKİ veya İdarece yapılır veya yaptırılır.

(8) Riskli alan ve rezerv yapı alanı dışında olup da bu Kanunun öngördüğü amaçlar bakımından güçlendirilebileceği teknik olarak tespit edilen yapılar için, Bakanlar Kurulunca belirlenen usul ve esaslar çerçevesinde Bakanlıkça dönüşüm projeleri özel hesabından güçlendirme kredisi verilebilir.

(9) Bu Kanun uyarınca tesis edilen idari işlemlere karşı tebliğ tarihinden itibaren otuz gün içinde 6/1/1982 tarihli ve 2577 sayll İdari Yargılama Usulü Kanunu uyarınca dava açılabilir. Bu davalarda yürütmenin durdurulmasina karar verilemez.

(10) Bu Kanun uyarınca yapılan iş ve işlemlere ilişkin olarak adrese dayalı nüfus kayıt sisteminde belirtilen adreslere yapılan tebligat, muhataplarına yapılmış sayılır.

(11) Bu Kanun hükümlerine göre Maliye Bakanlığınca Bakanlığa tahsis edilerek tasarrufuna bırakılan veya Bakanlı̆̆ın talebi üzerine TOKI'ye veya İdareye devredilen taşınmazlar üzerinde bu Kanun kapsamindaki uygulamalara bağll olarak meydana gelen yeni taşınmazlar Bakanlı̆̆ın, TOKI'nin veya İdarenin isteği üzerine, kendileri ile anlaşma sağlanan gerçek kişiler veya mirasçıları ile tüzel kişiler adına tapuya tescil olunur.

(12) Bakanlık, bu Kanunda belirtilen iş ve işlemlere ilişkin olarak TOKI'ye veya İdareye yetki devrine ve bu iş ve işlemlerden hangilerinin TOKİ veya İdare tarafından yapılacağını belirlemeye yetkilidir.

\subsection{Kanunun Uygulamaya Yansımaları}

Dönemin Çevre ve Şehircilik Bakanının beyanlarına göre ${ }^{4}$; Türkiye'deki 20 milyon konut stoğunun 6,5 milyonu aktif fay hatları üzerindedir; bunların yaklaşık 5 milyonu, Marmara Depreminden sonra yapılmış ve göreceli olarak depreme dayanıklı olduğu kabul edilmektedir. Deprem öncesinde inşa edilmiş olan 15 milyon konut vardır ve bunların yaklaşık 6,5 milyonu riskli durumdadır. Son 10 yılda Türkiye'de devlet eliyle 500 bin konut yapılmıştır. Bu süreçte 145 noktada belediyelerle işbirliği halinde kentsel dönüşüm projeleri yapılmış; 37 bin konut yapılarak teslim edilmiş, 67 bin konutun yapımı ise sürmektedir. Bu 10 y1llık süreçte özel sektör ise 4 milyon 500 bin konut inşa etmiştir. Yasayla birlikte Türkiye genelinde 20

\footnotetext{
4 “Büyük Dönüşüm Başladı” http://www.csb.gov.tr/turkce/index.php?Sayfa=faaliyetdetay\&Id=375 (5.11.2012)
} 
yılda 14 milyon konutun elden geçirilmesi planlanmaktadır. Dönüşümün Türkiye'ye maliyetinin 350-400 milyar dolar olması beklenirken, bu rakamın 100 milyar dolarlık bir bölümünün ise İstanbul'da gerçekleşmesi beklenmektedir.

6306 sayılı kanun kapsamında gerçekleştirilecek olan kentsel dönüşüm uygulamalarına 5 Ekim 2012 tarihinde 33 ilde (İstanbul, İzmir, Ankara, Kocaeli, Adana, Afyonkarahisar, Ağrı, Amasya, Aydın, Balıkesir, Bilecik, Bitlis, Bolu, Bursa, Çanakkale, Denizli, Düzce, Edirne, Elazığ, Erzurum, Gaziantep, Hakkâri, Hatay, Kahramanmaraş, Kırıkkale, Kırşehir, Malatya, Nevşehir, Samsun, Sinop, Tekirdağ, Tunceli, Van) başlanmıştır. Proje İstanbul-Esenler'de Havaalanı Mahallesinde Başbakan tarafından başlatılmış ve basın büyük ilgi göstermiştir. Proje ile 33 kentte, 65 noktada yaklaşık 6 bin 500 birim konutun yenilenmesi için yıkım başlatılmıştır.

Kentsel dönüşüm kapsamında en büyük dönüşüm İstanbul'da gerçekleşmektedir. Yıkıma riskli kamu binalarından başlanmış ${ }^{5}$; ardından İstanbul'da dönüşüm öncelikli olarak riskli alanlar olarak görülen Avcılar, Zeytinburnu, Ümraniye ve Pendik ilçelerinde devam etmiştir. Kartal'da 359 sitenin 170 tanesi incelenmiş, Bağlar, Tüm Emek ve Keper sitelerini kapsayan yaklaşık 5 bin kişinin yaşadığı 4 site projelendirilmiş, Bağcılar'da 11 dönüșüm alanı tespit edilmiştir. 270 bin metrekarelik alan içinde dört sitenin bulunduğu ve yaklaşık 5 bin kişinin yaşadığı alan projelendirilmiş; Beyoğlu-Örnektepe'de 25 bin metrekare alanı kapsayan 280 konutluk yaklaşık bin kişinin yaşadığı alan projelendirilmiş; Esenlerde Havaalanı ve Tuna mahallelerinde 1560 konutluk 100 bin metrekare alanı dönüşüme konu olmaktadır. Yeni konutların temeli 2013 başlarında atılmış ve devam etmektedir. 10 bin kişiyi ilgilendiren dönüşüm çalışmalarında yeşil ağrılıklı bir yapılaşma amaçlanmaktadır. Yeni projede 25-30 yıllık, daha önce 260 binanın olduğu bölgede sadece 19 bina, 60 binanın olduğu bölgede ise 2 bina planlanmaktadır. Uygulama ile Esenler'de, ayrıca Türkiye'nin ilk 'kentsel dönüşüm güçlendirme kredisi' için imzalar atılmıştır. Buna göre, evi risk altındaki hak sahipleri kendi 'bireysel dönüşümlerini' yapmak için kredi desteği alabilecektir. Tek bir kişi için maksimum 500 bin TL sınırında tutulan yenileme kredisinde ortalama tutarın ise bir daire için 60-70 bin TL olması beklenmektedir. Devlet desteği ile alınacak kredilerde vade süresi 10 yıla kadar uzamaktadır, faiz oranı ise $\% 0.55$ 'tir.

Bunların yanında İstanbul'da Bağcılar, Bayrampaşa-Vatan Mahallesinde 5583 birim konut dönüştürülmekte; Gaziosmanpaşa-Sarıgöl Mahallesi, Yıldıztabya Mahallesi, Fevzi Çakmak Mahallesi, Mevlana Mahallesi, Yenimahalle ve Barbaros Mahallesi'nden oluşan toplam 6 noktada 22.961 birim konutun dönüşümü gerçekleştirilmektedir. Kanun kapsamında İzmir'de Hava Teknik Okullar Komutanlığı'na ait lojmanlardaki 2 bina yıkımı ile başlamış ve Karşıyaka, Bostanlı Mahallesi ve diğer noktalarda 110 bin binanın dönüşümü devam etmektedir. Rize Timya Vadisi'nde, dere yataklarının oluşturduğu jeolojik mahsurlu alan niteliğindeki yerlerde inşa edilmiş 534 birim konut dönüştürülmektedir. Sakarya-Hendek Belediyesi Kemaliye Mahallesi'nde Kentsel Dönüşüm ve Gelişim Projesi uygulayarak; 266 adet konut ve 43 adet işyeri olmak üzere toplam 309 bağımsız birimin dönüşümü gerçekleştirilmiştir. Van'da ilk olarak depremde hasar gören Emniyet Müdürlüğü, İller Bankası Bölge Müdürlüğü binaları kentsel dönüşüm çalışmaları kapsamında yıkılmıştır. Diyarbakır-Suriçi'nde Tarihi Ulucami'nin etrafındaki sağlıksız, riskli ve estetik olmayan 371 birim konut dönüştürülmektedir ${ }^{6}$.

Bakanlığın çalışmalarıyla riskli alan tespiti için öncelikle 360 kuruluşa lisans verilmiş ve önce 13.386 ardında 33.529, toplamda 46.915 binanın yıkımı gerçekleşmiştir. Bakanlık, 2014 yılında 100 alanı; 650 bin

\footnotetext{
${ }^{5}$ Bu kapsamda Yeni Levent'te 33 daireli Milli Savunma Bakanlığı lojmanı, Sancaktepe'de MSB er pavyonu ve su kulesi, Sarıgazi'de MSB'ye ait 276 daireli 23 binadan oluşan lojman, Maltepe'de MSB'ye ait er pavyonu ile Şakir Gürkan Sağlık Ocağı, Hadımköy'de MSB'ye ait 6 daireli lojman, er pavyonu, karargah binası, Küçükyalı'da MSB'ye ait lojmanın su deposu, KBRN Eğitim Taburu er pavyonu, Tuzla'da subay ve astsubay yatma yeri, su kulesi, Çatalca'da Binkılıç Sağlık Ocağı, Şişli'de Okmeydanı Hastanesi A ve B Blok lojmanları, Mecidiyeköy Aile Sağlığı Merkezi, Sultangazi'de Lütfiye Nuri Burat Devlet Hastanesi, Sarıer'de İstinye Semt Polikliniği binası, Rumeli Feneri Aile Sağlık Merkezi, Kadıköy'de Semt Polis Hizmet Binası, Fatih'te Vilayetler Semt Polikliniğinin yıkılması planlanmaktadır.

${ }^{6}$ file:///C:/Users/VISTA/Desktop/kentsel_donusum_kitap.pdf (25.2.2014)
} 
dükkân ve konutun da riskli ilan edileceğini ve toplamda 400 bağımsız bölümün dönüşümünün gerçekleşmesini planlamaktadır.

\subsection{Kanun ve Uygulamaya Yönelik Eleştiriler}

Özellikle ana muhalefet partisi ve şehir plancıları odası, mimarlar odası gibi meslek odalarının uygulamalara ve tasarı aşamasından itibaren yasaya yönelik yoğun eleştirileri vardır. Ana muhalefet partisinin kanunun iptali ve yürürlüğünün durdurulması istemiyle Anayasa Mahkemesi'ne açtığı davada mahkeme 5393 sayılı Belediye Kanunun, 73. maddesinin 11. fikrasındaki, kentsel dönüşüm alanlarında devam eden inşaatlardan belediye izni olmayanların 5 yıl süreyle durdurulması, durdurmanın sürüp sürmeyeceğine belediyenin karar vermesi ve durdurma süresinin 10 yılı geçemeyeceğine ilişkin 2,3 ve 4 . cümlelerini anayasaya aykırı bulmuş ve yürütmesini durdurmuştur.

Yapılan eleştirilerin önemli bir bölümü genel olarak hükümet tarafından başlatılan Kentsel Dönüşüm Hareketine yöneliktir. Bu eleştirilerin büyük bölümü meslek odalarından gelmektedir. Eleştirilerin ana odakları şu şekilde sıralanabilir;

- Bu bir sermaye/mülk transferi tasarısıdır; inşaat sektörünü zengin etme amacındadır. Kamu yararına hizmet etmekten uzaktır. "Deprem risklerinin azaltılması" yapılanları meşrulaştırmak için kullanılmaktadır.

- Dönüşüm sadece ekonomik boyutları ile ele alınmakta, ortaya çıkaracağı sosyal sorunlar göz ardı edilmektedir. Rantı yüksek bölgelerde dönüşüm daha hılı olacak, bu da bölgeler arası adaletsizlikleri, yerlerinden edilen ev sahipleri, kiracılar ve esnaf nedeniyle yeni eşitsizlikler yaratacaktır; soylulaştırma ile yeni sınıfsal ve mekansal ayrımlar ortaya çıkacaktır. Bölge halkının yıllardır yaşadıkları yerlerden zorla tahliye edilmelerine, işlerini kaybetmelerine, borçlandırılmalarına, sosyal, ekonomik ve kültürel hak ihlallerine maruz kalmalarına ve insan hakları mağduriyetlerine yol açarak, yıllarca kurdukları ilişkilerinin yok olmasına yol açacaktır. Boşaltılan tüm bu yerlerin yerine lüks konut ve alışveriş merkezleri yapılarak; rantı inşaat şirketleri, yerel ve merkezi idareler tarafından paylaşılacaktır.

- Evleri dönüşüme konu olan vatandaşların yasanın getirdiği maliyetleri karşılama güçleri genellikle yoktur. Kiracılar için geliştirilen çözüm önerileri yeterli değildir.

- Kendine has özellikleri bulunan alanlar için o özelliklere uygun düzenlemeler/dönüşüm projeleri geliştirilmemiştir.

- Dönüşüm ile oluşan değer farkının nereye nasıl aktarılacağı, kamu yararına nasıl hizmet edeceği açık değildir.

- Dönüşümü denetleyen ve yönlendiren kurumsal ve yasal düzenlemelerin gerekli şekilde kurulamadığ1, planlama yaklaşımlarının ise genellikle dönüşümün gerisinden geldiği ve dünyadaki uygulama süreçleri yeterince sorgulanmadan kopyalanarak alınan projelerin Türk planlama sistemine eklendiği izlenmektedir.

- Kentsel dönüşüm süreci ile ilgili olarak vatandaş yeterince bilgilendirilmemekte; meslek odaları ve üniversitelerin katılımı sağlanmamaktadır" ${ }^{7}$

- Zorla el konulan özel mülkiyet ve hazine arazilerinin kullanımına yönelik yapım işleri, mal ve hizmet alımları şeffaflıktan uzak davetiye usulü ile ihale edilmektedir. Kamu kaynaklarının ihale ediliş biçimi, iktidara yakın kişi, kurum ve kuruluşlara pazar açıldığı endişesi yaşanmaktadır. ${ }^{8}$

Eleştirilerin önemli bir bölümü de 6306 s. yasa hükümlerine ilişkindir.

Yasanın 2. Maddesine ilişkin olarak;

\footnotetext{
7 “Kentsel Rant Yasası" http://www.arkitera.com/haber/index/detay/kentsel-rant-yasasi/10327 (29.10.2012)

${ }^{8}$ Hukuk İhlalinin Her Türlü Afete Zemin Hazırladığını Unutmadan!TBMM, Hükümetin Dayattığı Hukuk üstü Yetkileri Kabul Edecek Mi? http://www.mimarlarodasiankara.org/index.php?Did=4426 (29.10.2012)
} 
- Yetkinin genel olarak Çevre ve Şehircilik Bakanlığı`na verilmesi, yerleşmelerin asıl sorumlusu olan yerel yönetim birimlerinin devre dışı bırakılmasına neden olacağından yerel demokrasi fikrine aykırıdır.

- Ülkenin ve kentlerin tamamını "riskli alan" ilan etme olanağını sağlayarak, bu tanımla belirlenmiş alanlarda TOKI'yi ve dolayısıyla Başbakanlığı "tek imar otoritesi”" yaparak, merkezileşmeye yol açmaktadır.

- "Bakanlar Kurulunca belirlenecek rezerv alanlar" ve katılım olmadan saptanabilecek "riskli alanlar" ülkenin her yerinde keyfi olarak ilan edilebilecektir. "Rezerv yapı alanı" nın kapsamı, idare tarafından zeytinlikler, meralar, ormanlar, kıyılar, askeri bölgeler, sit alanları olarak da genişletilebilme potansiyeline sahiptir. ${ }^{9}$

- Riskli yapıların yanı sıra risk taşımayan yapıların da Bakanlığın belirleyeceği sınırların içinde kalmaları durumunda yıkılabilmesi; bu yapılarda oturan kişilerin hukuksal güvencelerini, barınma haklarını, konut dokunulmazlığını, belirsizlik taşıyan "uygulama bütünlüğ̈̈" kavramına dayanarak ortadan kaldırabilecektir.

Yasanın 3. Maddesine ilişkin olarak;

- Kamu ve özel mülkiyet idari kararla alınıp-satılabilinir, yaptırılabilinir, dönüştürülebilinir, gerek toplu gerekse zorunlu iskân olabilir, toplulaştırılıp- dağıtılabilinir hale gelmektedir. $\mathrm{Bu}$ iş ve işlemlerden kar edecekler de ancak idare tarafından tespit edilebilir. Riskli yapıları tespit etmekte "lisanslı kurumlar", itirazlarda "teknik heyet", kamulaştırma bedeline itirazlarda "değerleme şirketleri" yetkilidir. İdarelerde istihdam edilecek personele ilişkin ise hiç bir kayıt ve koşulun uygulanmayacağı yeni bir "sözleşmeli personel" statüsü belirlenmiştir.

- Kanunda "Bakanlıkça lisanslandırılmış kurum ve kuruluşlar" ile "teknik heyet"in tanımı olmadığı gibi statüleri de belirsizdir. Yönetmeliğe bırakılan bu oluşumların niteliği ve yetkileri idarenin takdirine bırakılmıştır. Riskli yapıların tespiti aşamasında büyük bir dayatma vardır. Lisans verilen kuruluşların TMMOB'ne bağlı odalar dışında yapı denetim şirketleri olması; müteahhit firmaların yapı denetim şirketleriyle işbirliği halinde çalışmaları yasanın sorunlu taraflarını oluşturmaktadır.

- Altyapı maliyetlerinin konutları yıktırılanlara ödetilmesi, yoksul kesimler için maliyeti yüksek, Anayasanın Hukuk Devleti ve Sosyal Devlet ilkeleri ile çelişen bir düzenlemedir. Yasada yapılan "gerekli görüldüğünde Bakanlar Kurulu kararı ile sosyal donatı ve altyapı harcamaları uygulama maliyetine dâhil edilmeyebilir" biçimindeki istisna düzenlemesi, genel olarak sosyal donatı ve altyapı harcamalarının maliyete ekleneceğini göstermektedir.

Yasanın 4. Maddesine ilişkin olarak;

- Riskli alanlardaki yapılara verilen kamusal hizmetlerin durdurulmasına ilişkin düzenleme, barınma hakkına ve sosyal devlet ilkesine aykırı olduğu gibi önemli sağlık ve güvenlik sorunlarını da ortaya çıkarabilir.

Yasanın 5. Maddesine ilişkin olarak;

- Riskli yapı tespiti yapıldıktan sonra itiraz edilmesi halinde itirazın kabul görmemesi ve yıkımın kesinleşmesi durumunda idare 60 günlük süre içinde yapının yıkılmasını isteyecektir. Bu sürede yıkılmayan yapılar için makul süre verilmektedir, ancak makul sürenin ne kadar olduğu açık değildir. Yıkım maliyeti de tapuya hisse oranında yıkım bedeli olarak yansıtılmaktadır ${ }^{10}$.

Yasanın 6. Maddesine ilişkin olarak;

- Tesis edilen idari işleme karşı 30 gün içinde dava açılabilmesi ancak yürütmeyi durdurma kararı verilememesi idari davalara karşı 60 günlük dava açma hakkı ile çelişmekte, idarenin denetim yollarından yargısal denetim devre dışı bırakılmaktadır ${ }^{11}$.

\footnotetext{
${ }^{9} \mathrm{http}$ //www.ankarabarosu.org.tr/Dosyalar/yie/AFET.pdf (29.10.2012)

10 "Kentsel Rant Yasası" http://www.arkitera.com/haber/index/detay/kentsel-rant-yasasi/10327 (29.10.2012)

${ }^{11} \mathrm{http}: / /$ www.ankarabarosu.org.tr/Dosyalar/yie/AFET.pdf (29.10.2012)
} 
- Yasaya göre, mal sahipleri 2/3'lük orana ulaşılamazsa, devreye 'acele kamulaştırma' girmektedir. Bu kuralın hak ihlallerine ve pek çok anlaşmazlığa yol açması muhtemeldir. Mülk sahipleri hem evlerini kaybetmekte; hem de paralarını taksitler halinde ancak beş yıl sonra alabilmektedir. 2/3 kuralı müteahhitler tarafından da halkın tehdit edilmesine aracılık eden bir araç haline gelmiş durumdadır. Bu anlamda yasa uzlaşmadan ziyade dayatma anlamındadır ${ }^{12}$. Bu itirazlar nasıl sonuca bağlanacaktır? Bunu hangi komisyon değerlendirip karara bağlayacaktır? Lisanslandırılmış kuruluş tespit aşamasında görevlendirilmiştir ama itiraz aşamasında nasıl değerlendirileceğini yasa belirlememiştî ${ }^{13}$.

Yasanın 7. Maddesine ilişkin;

- Kamulaştırma davalarında bilirkişilik yapan mimar ve mühendislere bilirkişilik yolu kapatılarak; değerleme şirketlerine öncelik tanınmıştır.

- Bilirkişi seçiminde hâkimin takdir hakkını elinden alan, yargılamanın bir unsuru olmadığı halde valilikleri yargılama sürecine katan bir süreç adil bir kararın verilmesini güçleştirmektedir.

- Riskli yapıların tahliyesi, yıkma ve yıktırma işi, işlem ve değerleme işlemlerini "engelleyici" fiilde bulunanlar hakkında Türk Ceza Yasası gereğince suç duyurusu, bu eylemleri engellemeyen kamu görevlileri hakkında da ceza ve disiplin hükümlerinin uygulanacağı biçiminde yapılan düzenlemeyle de kimsenin mülkiyetine ilişkin bir hakkı kullanamayacağı hem halka hem de kamu görevlilerine gözdağı verme mahiyetindedir, barınma hakkının savunulmasına karşı bir tehdittir ${ }^{14}$.

- Yasanın "Uygulanmayacak mevzuat" başlıklı maddesinde yapılan düzenleme ile ülkemizin sahip olduğu önemli doğal ve kültürel zenginlikleri koruma altına alan yasal kurallardan vazgeçilmektedir.

- Yasanın ismi "afet riski taşıyan alanların dönüştürülmesi" iken aslında bir "torba yasa" özelliği taşımaktadır. Yasanın kendisi gerçekte yürürlükle birlikte on madde olup, diğer tüm maddeler Genel Bütçe dâhil diğer kanunlarda değişiklik yapılmasını düzenlemektedir. Kanunun uygulanmasında 14 kanunun engelleyici hükümlerinin uygulanmayacağı, bu on dört kanunun yanında gözden kaçmış diğer kanunlarda engelleyici hükümler var ise bunların da uygulanmayacağı hükme bağlanmaktadır. Uygulanmayacak yasaların yanında, tasarı ile on bir yasanın maddesi değişmekte ya da yeni hükümler eklenmekte ve iki yasa yürürlükten kalkmaktadır ${ }^{15}$.

- Arkeolojik ve tarihi sit alanlarında yapılacak tespitlerde hangi bilimsel kriterler çerçevesinde değerlendirme yapılacağı ile ilgili açıklayıcı ifadelerin yer almadığı yasa; kültürel ve tarihi varlıkların korunmasını amaçlayan kanun, yönetmelik, ilke kararları ile çelişmektedir. Yasa, yeraltı ve yerüstü kültür varlıklarını göz ardı etmekte, sahip olunan kültürel birikimin yok olmasına yol açacaktır ${ }^{16}$.

\footnotetext{
12 "Kentsel Rant Yasası" http://www.arkitera.com/haber/index/detay/kentsel-rant-yasasi/10327 (29.10.2012)

13 “Kentsel Rant Yasası” http://www.arkitera.com/haber/index/detay/kentsel-rant-yasasi/10327 (29.10.2012)

${ }^{14}$ Afet Riski Altındaki Alanların Dönüştürülmesi Hakkında Kanun" İnsan Haklarına Ve Anayasa'ya Aykırıdır.

${ }^{15}$ Tasarı ile Orman (kent veya çeperindeki ormanlık alanların kullanımına yönelik), Gecekondu, Toplu Konut, İmar, Yıpranan Tarihi ve Kültürel Taşınmaz Varlıkların Yenilenerek Korunması, İskân, İller Bankası Anonim Şirketi Hakkında Kanunlara ve Genel Kadro ve Usulü Hakkında KHK`ye yeni maddeler eklenmekte; Kamulaştırma Yasası'nın bilirkişilikle ilgili maddesi ile Yıpranan Tarihi ve Kültürel Taşınmaz Varlıkların Yenilenerek Korunması ve Yaşatılarak Kullanılması Kanunu, Çevre Şehircilik Bakanlığının Teşkilat ve Görevleri Hakkında KHK değişmekte, Atatürk‘ün doğumunun 100‘üncü Yılının Kutlanması ve Atatürk Kültür Merkezi Kurulması Hakkında Kanun ile İmar ve Gecekondu Mevzuatına Aykırı Yapılara Uygulanacak Bazı İşlemler ve 6785 sayılı İmar Kanununun Bir Maddesinin Değiştirilmesi Hakkında kanunlar ise yürürlükten kaldırılmaktadır.

16 “Afet Riski Altındaki Alanların Dönüştürülmesi Hakkında Kanun”a Yönelik Ortak Deklarasyon http://www.spoist.org/basin-aciklamalari/afet-riski-altindaki-alanlarin-donusturulmesi-hakkinda-kanun-a-yonelik-ortakdeklarasyon (29.10.2012)
} 


\section{Sonuç}

6306 sayılı yasa, eleştirilere rağmen, ülkemizde bugüne kadar doğal afet risklerinin azaltılması çerçevesinde atılan en önemli adımlardan biri olmasıyla hakkı teslim edilmelidir. Marmara Depreminin neden ağır olduğu ekonomik kayıplar hatırlandığında özellikle İstanbul'da bu türden bir dönüşümün başlatılmasının önemi daha iyi anlaşılabilecektir.

Yasa, kentsel dönüşüme ilişkin olarak daha önceki dönemde dile getirilen "bütüncül mevzuat eksikliği", sorununa bir ölçüde çözüm getirmeyi amaçlaması itibariyle de olumlu bir düzenlemedir. Yasa ile bütüncül bir bakış açısıyla sadece kentin tarihi, arkeolojik parçalarını, kentsel sit alanlarını değil, kentin tamamının fiziksel, sosyal ve ekonomik olarak ele alınması mümkün olmuştur. Bu özelliği ile kanun diğer projeler için bir altlık oluşturabilecek ve buna dayanarak alana/bölgeye özel düzenlemeler de yapılabilecektir.

Ancak eleştirilerden de yola çıkılarak yasal düzenleme ve uygulamaların iyileştirilmesi noktasında bazı öneriler getirilebilir;

- Kamu ile özel ve sivil toplumun ortaklaşa hareket etmesi, vatandaşın sürece dâhil edilmesi, projelerin anlatılması, halkın ikna edilmesi sürecin başarısı açısından önem taşımaktadır.

- Benzer dönüşüm projelerinde diğer ülkelerin deneyimleri, finansman modelleri, uyguladıkları dönüşümün sosyal boyutu çerçevesinde yaptıkları çalışmalar dikkatlice incelenmeli, aktarılmalıdır.

- Kentsel dönüşüm sonucunda oluşan rantın adilane biçimde dağıtılması, kamuya dönük projelere aktarılması sağlanmalıdır.

- Proje, kamu öncülüğünde başlatılmasına rağmen sivil toplum ve özel sektör tarafindan da desteklenmeli, özel sektörün müdahil olduğu noktalarda hak mağduriyetlerinin oluşmaması için gereken tedbirler alınmalıdır.

- Kentsel dönüşüm uygulaması yapılacak yerlerde, ilgili idare tarafından, proje ile hedeflenen sonucun ortaya çıkmasına hizmet edecek ancak, bireylerin mülkiyet hakkına en az müdahalede bulunacak yöntem tercih edilmelidir

- Ülkemizdeki kentsel arsa çok hisseli ve imar parselleri küçüktür. Ruhsatsız yapı çokluğu nedeniyle de fiili durumlar ortaya çıkmaktadır. Dolayısıyla öncelikle mülkiyet yapısındaki sorunlar giderilmelidir.

- Dönüşüm yapılacak alanlardaki sorunlar çok boyutlu olduğundan klasik planlama anlayışı ve imar mevzuatı artık yetersiz kalmaktadır. Bundan dolayı, planlama sisteminin değişime ihtiyacı vardır. 


\section{KAYNAKÇA}

DEVLET PLANLAMA TEŞKİLATI (2004), Türkiye İktisat Kongresi-Afet Yönetimi Çalışma Grubu Raporu Sunuş Metni, İzmir.

DURSUN, Pelin, EKMEKÇİ T. OYA (2010), "Mapping Urban Transformation via New Housing Projects in the City of Istanbul", Urban Dynamics\&Housing Change - crossing into the 2nd decade of the 3rd millennium

GENÇ, Fatma Neval (2012), "Yerel Yönetimler ve Kent Yenileme”, Yerel ve Kentsel Politikalar, (Ed. M.A. Çukurçayır, A. Tekel), Çizgi Kitabevi, Konya, s.137-168.

GERAY, Cevat (1968), “Gecekondu Sorununa Toplu Bakış”, Amme İdaresi Dergisi, 1 (2), s.11-28.

HEPER, Metin (1979), “Türkiye’de Gecekondu Politikası Üzerine Bazı Düşünceler”, Amme İdaresi Dergisi, $12(4)$, s. 55-62.

KELEŞ, Ruşen (2008), Kentleşme Politikası, İmge Kitabevi, Ankara.

KIRAY, Mübeccel (1982), "Modern Şehirlerin Gelişmesi ve Türkiye’ye Has Bazı Eğilimler”, Toplumbilim Yazıları, (Gazi Üniversitesi İ̈BF Yayın No: 7), Ankara, s. 265-273.

MUTLU, Selcen (2007), Türkiye'de Yaşanan Gecekondulaşma Süreci ve Çözüm Arayışları: Ankara Örneği, (AÜ SBE, Yayınlanmamış Yüksek Lisans Tezi).

SÖNMEZ, Nihan, Özdemir (2006), "Düzensiz Konut alanlarında Kentsel Dönüşüm Modelleri Üzerine Bir Değerlendirme", Planlama, 2, s. 121-127.

T.C. BAYINDIRLIK VE İSKÂN BAKANLIĞI (2004), Deprem Şurası Afet Bilgi Komisyonu Raporu, Ankara.

T.C. ÇEVRE VE ŞEHIRCILIK BAKANLIĞI (2014), Kentsel Dönüşümle Afetlere Hazır Türkiye

TEKELİ, İlhan (1991), Kent Planlaması Konuşmaları, TMMOB Yayını, Ankara. (2001) Modernite Aşı1ırken Kent Planlaması, İmge Kitabevi, Ankara. 